RHR 238(a)

Draft

Published as "Historical Foundations and Enduring Fundamentals of American Religious Freedom," Journal of the Society of Christian Ethics 33 (2020): 156-167

\title{
Historical Foundations and Enduring Fundamentals of American Religious Freedom
}

\author{
John Witte, Jr.*
}

\begin{abstract}
The eighteenth-century American founders believed that religion is special and deserves special constitutional protection, and that all peaceable faiths must be drawn into the constitutional process and protection. The founders introduced six constitutional principles for the protection of religious freedom - freedom of conscience, free exercise of religion, religious pluralism, religious equality, separation of church and state, and no state establishment of religion. Since the 1940s, the United States Supreme Court has upheld these religious freedom principles in more 170 cases, albeit unevenly of late. Moreover, in recent years religious freedom has come under sharp popular and academic attack, particularly as religious pathologies have come to light and religious freedom claims have clashed with sexual liberty claims. This Essay calls for a return to the first principles of religious freedom for all, at home and abroad, and for a new balance between religious freedom and other fundamental rights claims.
\end{abstract}

Keywords: First Amendment; religious freedom; John Adams; James Madison; United States Supreme Court

\section{Founding Principles of Religious Freedom}

'A page of history is worth a volume of logic,' Oliver Wendell Holmes, Jr. once wrote. ${ }^{1}$ In that spirit, this brief Article sketches the

*Robert W. Woodruff Professor of Law, McDonald Distinguished Professor of Religion, and Director of the Center for the Study of Law and Religion, Emory University. This brief article draws in part from John Witte, Jr. and Joel A. Nichols, Religion and the American Constitutional 
historical context for the logical and doctrinal articles on modern AngloAmerican religious freedom that comprise the bulk of this symposium issue. I focus first on the American founding era of 1760 to 1820 , and leading founders like John Adams, Thomas Jefferson, and James Madison. Like their English counterparts, ably described in the prior Article by Mark Hill, the American founders drew deeply on the Western legal tradition. They, too, were inspired by biblical, classical, and republican theories of liberty. ${ }^{2}$ They, too, drew on Magna Carta and the common law tradition of rights and liberties that it inspired. ${ }^{3}$ Especially important for the American founders were seventeenth-century constitutional developments in England from the 1628 Petition of Right to the 1689 Bill of Rights, and the defenses of religious and civil rights and liberties by great English minds like Edward Coke, John Milton, and John Locke, and their colonial allies in the New World like Roger Williams, Nathaniel Ward, and William Penn. ${ }^{4}$

But the later eighteenth century in America was also an era of violent revolution against England's political, religious, military, and economic establishment. In its place, the American founders unleashed what Thomas Jefferson called a 'fair' and 'novel experiment' of guaranteeing religious freedom to all and religious establishment to none. ${ }^{5}$ These religious freedom guarantees, set out in the new state and federal constitutions forged between 1776 and 1833, defied the millennium-old assumptions inherited from Western Europe-that one form of Christianity must be established in a community and that the state must protect and support it against all other forms of faith. America would no longer suffer such governmental prescriptions and proscriptions of religion. All forms of Christianity had to stand on their own feet and on an equal footing with all other religions. Their survival and growth had to turn on the cogency of their word, not the coercion of the sword, on the faith of their members, not the force of the law.

Experiment (New York/Oxford: Oxford University Press, , $4^{\text {th }}$ ed., 2016) and is used herein with permission of the publisher.

${ }^{1}$ New York Trust Co. v. Eisner, 256 U.S. 345, 349 (1921).

${ }^{2}$ See the collection of sentiments in in Philip B. Kurland and Ralph S. Lerner, eds., The Founders' Constitution, 5 vols. (Indianapolis, IN: Liberty Fund, repr. ed., 2000).

${ }^{3}$ See Robin Griffith-Jones and Mark Hill, eds., Magna Carta, Religion, and the Rule of Law (Cambridge: Cambridge University Press, 2015), pp. 81-156.

${ }^{4}$ John Witte, Jr., The Reformation of Rights: Law, Religion, and Human Rights in Early Modern Calvinism (Cambridge: Cambridge University Press, 2007), pp. 209-320.

${ }^{5}$ Julian Boyd (ed.), The Papers of Thomas Jefferson, 16 vols. (Princeton, NJ: Princeton University Press, 1950-1990), vol.1, pp. 537-39. See analysis in Sidney E. Mead, The Lively Experiment: The Shaping of Christianity in America (New York: Harper \& Row, 1963), pp. 55-71. 
John Adams, leading Massachusetts jurist and future American president, offered a robust appraisal of this new American constitutional experiment:

The people in America have now the best opportunity and the greatest trust in their hands, that Providence ever committed to so small a number, since the transgression of the first pair [Adam and Eve]; if they betray their trust, their guilt will merit even greater punishment than other nations have suffered, and the indignation of Heaven. ...

The United States of America have exhibited, perhaps, the first example of governments erected on the simple principles of nature; and if men are now sufficiently enlightened to disabuse themselves of artifice, imposture, hypocrisy, and superstition, they will consider this event as [a new] era in their history. Although the detail of the formation of the American governments is at present little known or regarded either in Europe or in America, it [is] destined to spread over the northern part of ... the globe....

The institutions now made in America will not wholly wear out for thousands of years. It is of the last importance, then, that they should begin right. If they set out wrong, they will never be able to return, unless it be by accident, to the right path. ... [T] he eyes of the world are upon [us]. ${ }^{6}$

More than two centuries later, Adams's sentiments prove remarkably prescient. For all of their failures and shortcomings, the eighteenth-century founders did indeed begin on the right 'path' toward a free society, and today, Americans enjoy a good deal of religious, civil, and political freedom as a consequence. American principles of religious

\footnotetext{
${ }^{6}$ Charles F. Adams (ed.), The Works of John Adams, Second President of the United States, 9 vols. (Boston, MA: Little and Brown, 1850-1857), vol. 4, pp. 290, 292-93, 298; vol. 8, p. 487. See also Terence Ball (ed.), The Federalist: Hamilton, Madison and May (Cambridge: Cambridge University Press, 2003), Paper No. 37 (James Madison), p. 173 (writing of the formation of the Constitution that ' $[\mathrm{i}] \mathrm{t}$ is impossible for the man of pious reflection not to perceive in it, a finger of that Almighty hand which has been so frequently and signally extended to our relief in the critical stages of the revolution')
} 
freedom have had a profound influence around the globe, and they now figure prominently in a number of national constitutions and international human rights instruments issued by political and religious bodies. ${ }^{7}$

To be sure, as Adams predicted, there has always been a 'glorious uncertainty of the law' of religious liberty and a noble diversity of understandings of its details. ${ }^{8}$ This was as true in Adams's day as in our own. In Adams's day, there were competing models of religious liberty that were more overtly theological than his-whether Puritan, Evangelical, Catholic, Quaker, or Anglican in inspiration. There were also competing models that were more overtly philosophical than his-whether Neoclassical, Republican, Whig, or Liberal in inclination. ${ }^{9}$ Today, these and other founding models of religious liberty have born ample progeny, and the great rivalries among them are fought out in the courts, legislatures, and academies throughout the land and, increasingly, the world.

Prone as he was to a dialectical model of religious liberty, Adams would likely approve of our rigorous rivalries of principle-so long as the rivals themselves remain committed to constitutional ideals of democratic order, rule of law, and ordered liberty for all. But Adams would also likely insist that we reconsider his most cardinal insights about the necessary dialectical nature of religious freedom and religious establishment. Too little religious freedom, Adams insisted, is a recipe for hypocrisy and impiety. But too unbridled religious freedom is an invitation to license and criminality. Too firm a religious establishment breeds coercion and corruption. But too little concern for religion allows anti-religious prejudices to become constitutional prerogatives. Somewhere between these extremes, Adams believed, a society must find its balance. ${ }^{10}$

One key to re-striking this constitutional balance today lies in the eighteenth-century founders' most elementary insight-that religion is special and needs special protection in the Constitution. '[W]e cannot repudiate that decision without rejecting an essential feature of constitutionalism, rendering all constitutional rights vulnerable to

\footnotetext{
${ }^{7}$ Witte \& Nichols, Religion and the American Constitutional Experiment, pp. 250-55; John T. Noonan, Jr., The Lustre of our Country: The American Experience of Religious Freedom (Berkeley, CA: University of California Press, 2000); W. Cole Durham, Jr. and Brent W. Scharffs, Law and Religion: National, International, and Comparative Perspectives (New York: Wolters Kluwer, 2d. ed., 2019).

8 John Adams, 'Letter from John Adams to Josiah Quincy (Feb. 9, 1811),' in Adams, Works, vol.

9, p. 630.

${ }^{9}$ Witte \& Nichols, Religion and the American Constitutional Experiment, pp. 24-40.

${ }^{10}$ John Witte, Jr., 'A Most Mild and Equitable Establishment of Religion': John Adams and the Massachusetts Experiment,' Journal of Church and State 41 (1999), pp. 213, 216.
} 
repudiation if they go out of favor,' writes Douglas Laycock. ${ }^{11}$ Although America's religious landscape has changed, religion remains today a unique source of individual and personal identity for many, involving 'the duty which we owe to our Creator, and the manner of discharging it,' in James Madison's words. ${ }^{12}$ The founders' vision was that religion is more than simply another form of speech and assembly, privacy and autonomy; it deserves separate constitutional treatment. The founders thus placed freedom of religion alongside freedoms of speech, press, and assembly, giving religious claimants special protection and restricting government in its interaction with religion. Religion is also a unique form of public and social identity, involving a vast plurality of sanctuaries, schools, charities, missions, and other forms and forums of faith. All peaceable exercises of religion, whether individual or corporate, private or public, properly deserve the protection of the First Amendment. And such protection sometimes requires special exemptions and accommodations that cannot be afforded by general laws. ${ }^{13}$ 'The tyranny of the majority,' James Madison reminds us, is particularly dangerous to religious minorities. ${ }^{14}$

A second key to re-striking this constitutional balance lies in the eighteenth-century founders' insight that, in order to be enduring and effective, the constitutional process must seek to involve all voices and values in the community-religious, nonreligious, and anti-religious alike. Healthy constitutionalism ultimately demands 'confident pluralism,' in John Inazu's apt phrase. ${ }^{15}$ Thus in creating the new American constitutions, the founders drew upon all manner of representatives and voters to create and ratify these new organic laws. Believers and skeptics, churchmen and statesmen, Protestants and Catholics, Quakers and Jews, Civic Republicans and Enlightenment Liberals-many of whom had slandered if not slaughtered each other with a vengeance in years past-now came together in a rare moment of constitutional solidarity. The founders understood that a proper law of religious liberty required that all peaceable religions and believers participate in both its creation and its unfolding. To be sure, both in the founders' day and in subsequent generations, some Americans showed little concern for the religious or civil rights of Jews, Catholics, Mormons, Native Americans, Asian Americans, or African

\footnotetext{
${ }^{11}$ Douglas Laycock, 'Religious Liberty as Liberty,' Journal of Contemporary Legal Issues 7 (1996): pp. 313, 314

12 James Madison, 'Article on Religion Adopted by Convention (June 12, 1776), in William T. Hutchinson \& William M.E. Rachal (eds.), The Papers of James Madison, 17 vols. (Chicago, IL: University of Chicago Press, 1962-1991), vol. 1, p. 175.

${ }^{13}$ Witte \& Nichols, Religion and the American Constitutional Experiment, pp. 99-101 (regarding the meaning of liberty of conscience in the founding era).

${ }^{14}$ James Madison, 'Letter from James Madison to Thomas Jefferson (Oct. 17, 1788), in Gaillard Hunt, (ed.), The Writings of James Madison (New York: G.P. Putnam's Sons, 1904-1908), vol. 5, p. 272.

15 John D. Inazu, Confident Pluralism: Surviving and Thriving Through Deep Difference (Chicago, IL: University of Chicago Press, 2016).
} 
Americans, and too often inflicted horrible abuses upon them. And today, some of these old prejudices are returning anew in bitter clashes over race, immigration, and refugees, and in fresh outbreaks of nativism, antiSemitism, and Islamophobia. But a generous willingness to embrace all peaceable religions in the great project of religious freedom is one of the most original and compelling insights of the American experiment. As John Adams put it, religious freedom 'resides in Hindoos and Mahometans, as well as in Christians; in Cappadocian monarchists, as well as in Athenian democrats; in Shaking Quakers, as well as in ... Presbyterian clergy; in Tartars and Arabs, Negroes and Indians'-indeed in all 'the people of the United States.' ${ }^{16}$

A third key to re-striking this constitutional balance lies in balancing the multiple principles of religious liberty that the founders set forth in the frugal, sixteen-word phrase of the First Amendment: 'Congress shall make no law respecting an establishment of religion, or prohibiting the free exercise thereof. ${ }^{17}$ These were twin guarantees of religious liberty for all. The free exercise guarantee outlaws government proscriptions of religion-actions that unduly burden the conscience, restrict religious expression and activity, discriminate against religion, or invade the autonomy of churches and other religious bodies. The no-establishment guarantee outlaws government prescriptions of religion-actions that unduly coerce the conscience, mandate forms of religious expression and activity, discriminate in favor of religion, or improperly ally the state with churches or other religious bodies. The First Amendment guarantees of no establishment of any religion and free exercise of all religion thereby provided complementary protections to the other constitutive principles of the American experiment-liberty of conscience, religious equality, religious pluralism, and separation of church and state. ${ }^{18}$

\section{The Modern Era of Religious Freedom in the United States}

These three insights were not only part of the original vision of the eighteenth-century founders; they were also part of the original vision of the Supreme Court as it created the modern constitutional law of religious freedom. All three insights recur in Cantwell v. Connecticut $(1940)^{19}$ and

\footnotetext{
${ }^{16}$ John Adams, 'Letter from John Adams to John Taylor (Apr. 15, 1814),' in Adams, Works, vol. 6, p. 474; see also John Adams, 'Letter from John Adams to Thomas Jefferson (June 28, 1813),' in Lester J. Cappon, (ed.), The Adams-Jefferson Letters (Chapel Hill, NC: University of North Carolina Press, 1959), vol. 2, pp. 339-40.

${ }^{17}$ U.S. Const. amend. I.

${ }^{18}$ Witte \& Nichols, Religion and the American Constitutional Experiment, pp. 92-94.

19310 U.S. 296, 303-04, 310 (1940).
} 
in Everson v. Board of Education (1947), ${ }^{20}$ the two landmark United States Supreme Court cases that first applied the First Amendment religion clauses to the states and inaugurated the modern era of religious liberty in America.

Cantwell and Everson declared anew that religion had a special place in the Constitution and deserved special protection in the nation. In a remarkable counter-textual reading, the Supreme Court took it upon itself and the federal judiciary to enforce the First Amendment religion clauses against all levels and branches of government in the nation. The Court 'incorporated' the First Amendment religion clauses into the Fourteenth Amendment Due Process Clause, thereby creating a common and special law of religious freedom applicable throughout the nation. 'Congress shall make no law' now became, in effect, 'Government shall make no law respecting an establishment of religion, or prohibiting the free exercise thereof.' More than 170 religious freedom cases have reached the Supreme Court since 1940 (only 48 cases had reached the Court in the prior 150 years). Fully $80 \%$ of these post- 1940 cases dealt with state and local government issues, and roughly half of the cases found constitutional (and related statutory) violations. ${ }^{21}$ And for each of these Supreme Court cases, there was scores, sometimes hundreds, of cases in the lower courts. While this universalization of First Amendment religious liberty after 1940 angered individual states' rights activists, then and now, it was the growing local bigotry at home and abroad that compelled the Court to act. Local bigotry was also the reason that America and the world embraced religious freedom in the 1940s as a universal and nonderogable human right of all persons - one of the famous 'four freedoms' that Roosevelt championed to rebuke the horrific abuses inflicted on Jews and other religious and cultural minorities during World War II. Religious freedom for all was considered too important and universal a right to be left to the political calculus of state or local governments.

Cantwell and Everson also declared anew that all religious voices were welcome in the modern constitutional process of protecting religious liberty. These two cases welcomed hitherto marginal voices: Cantwell welcomed a devout Jehovah's Witness who sought protections for his very unpopular missionary work. Everson welcomed a skeptical citizen who sought protection from paying taxes in support of religious education. Subsequent cases have drawn into the constitutional dialogue a host of other religious and anti-religious groups-Catholics, Protestants, and Orthodox Christians; Jews, Muslims, and Hindus; Mormons, Quakers, and Hare Krishnas; Wiccans, Santerians, and Summumites; Skeptics, Atheists, and Secularists. While critics have charged the Court with

${ }^{20} 330$ U.S. 1,16 (1947).

${ }^{21}$ A table of all Supreme Court cases on religious freedom from 1815-2016 is in Witte \& Nichols, Religion and the American Constitutional Experiment, pp. 303-37. 
favoring Christians and Christian traditions over others, and with clumsily applying Christian categories of religion to measure the faith claims of others, the Court has been surprisingly solicitous of a number of new and minority religions, even though blind spots remain, notably in dealing with Native American Indian claims. ${ }^{22}$

And Cantwell and Everson declared anew the efficacy of the founding principles of the American experiment in religious freedom. The Free Exercise Clause, the Cantwell Court proclaimed, protects '[f]reedom of conscience and freedom to adhere to such religious organization or form of worship as the individual may choose.' It 'safeguards the free exercise of the chosen form of religion,' the 'freedom to act' on one's beliefs. It protects a plurality of forms and expressions of faith, each of which deserves equal protection under the law. 'The essential characteristic of these liberties is, that under their shield many types of life, character, opinion and belief can develop unmolested and unobstructed. ${ }^{23}$ The Establishment Clause, the Everson Court echoed, means that no government 'can set up a church'; 'can force nor influence a person to go to or to remain away from church against his will or force him to profess a belief or disbelief in any religion'; can 'punish [a person] for entertaining or professing religious beliefs or disbeliefs, for church attendance or nonattendance'; 'can, openly or secretly, participate in the affairs of any religious organizations or groups and vice versa.' Government may not 'exclude individual Catholics, Lutherans, Mohammedans, Baptists, Jews, Methodists, Non-believers, Presbyterians, or the members of any other faith, because of their faith, or lack of it, from receiving the benefits of public welfare legislation' or participating in the American public arena or political process. ${ }^{24}$

\section{New Attacks on Religious Freedom}

As later articles in this symposium document, religious freedom has come under increasing attack in America in recent years. Some of these attacks the Supreme Court has brought on itself. Some of its recent opinions have both weakened the First Amendment religion clauses, and introduced conflicting logics and contradictory tests that have left lower courts and legislatures without clear enough direction. In response, leading scholars now write openly that America's experiment in religious

\footnotetext{
${ }^{22}$ See, e.g., Torcaso v. Watkins, 367 U.S. 488 (1961) (upholding an atheist's claim that a mandatory oaths proclaiming a belief in God is unconstitutional); Holt v Hobbs, 135 S. Ct. 2218 (2015) (upholding a Muslim prisoner's statutory right to maintain a longer beard contrary to state prison regulations).

${ }^{23}$ Cantwell, 310 U.S. at 303, 310.

${ }^{24}$ Everson, 330 U.S. at $15-16$.
} 
freedom is a 'foreordained failure,' an 'impossibility' to achieve, and is sliding into its 'twilight.' ${ }^{25}$ Other scholars are trying to accelerate this decline by strongly attacking the idea that religion deserves any special constitutional consideration at all, and warning the populace against 'the perils of extreme religious liberty. ${ }^{26}$ 'Why tolerate religion?' reads an influential recent text, given that it is so irrational, unscientific, nonsensical, categorical, abstract, and impervious to empirical evidence or common sense. ${ }^{27}$

Religions have also brought some of these attacks on themselves. The horrors of 9/11 and scores of later attacks as well as the bloody and costly wars against Islamist terrorism have renewed traditional warnings that religion is a danger to modern liberty. The New York Times ran a sensational six-part exposé describing the 'hundreds' of special statutory protections, entitlements, and exemptions that religious individuals and groups quietly enjoy, prizes extracted by a whole phalanx of religious lobbyists in federal and state legislatures. ${ }^{28}$ The Catholic Church has been rocked by an avalanche of news reports and lawsuits about the pedophilia of delinquent priests and cover-ups by complicit bishops-all committed under the thick veil of religious autonomy and corporate religious freedom. ${ }^{29}$ Evangelical megachurches have faced withering attacks in Congress and the media for their massive embezzlement of funds, and the lush and luxurious lifestyles of their pastors--all the while enjoying tax exemptions for their incomes, properties, and parsonages. ${ }^{30}$ And Evangelical and mainline Protestants also now face their own new public reports of massive sex abuses by their clergy and other church

\footnotetext{
${ }^{25}$ Steven D. Smith, Foreordained Failure: The Quest for a Constitutional Principle of Religious Freedom (Oxford: Oxford University Press, 1995); Winnifred Sullivan, The Impossibility of Religious Freedom (Princeton, NJ: Princeton University Press, 2005); David Sehat, The Myth of American Religious Freedom (New York: Oxford University Press, 2011); Symposium, 'Rethinking Religious Freedom,' Journal of Law and Religion 29 (2014), pp. 355-547; Symposium, 'Is Religion Outdated (as a Constitutional Category),' San Diego Law Review 51 (2014), pp. 971-1133.

${ }^{26}$ Marci A. Hamilton, God v. the Gavel: The Perils of Extreme Religious Liberty (Cambridge: Cambridge University Press, rev. ed. 2014).

${ }^{27}$ Brian Leiter, Why Tolerate Religion? (Princeton, NJ: Princeton University Press, 2013).

${ }^{28}$ Diana B. Henriques, 'In God's Name,' New York Times (October 8-11, 20, November 23, and December 19, 2006). See further Diana B. Henriques and Andfrew W. Lehren, 'Religious Groups Reap Federal Aid for Pet Projects,' New York Times (May 13, 2007); id., 'Federal Grant for a Medical Mission Goes Awry,' New York Times (June 13, 2007).

${ }^{29}$ See, e.g, See, e.g., Testimony by His Excellency Carlo Maria Viganò, http://online.wsj.com/media/Viganos-letter.pdf (last visited Mar. 26, 2019) (detailing Archbishop Viganò's blistering indictment of the papacy concerning the pedophilia of Cardinal McCarrick and the cover-up by the Vatican);

${ }^{30}$ See, e.g., Press Release, Senator Chuck Grassley, 'Grassley Seeks Information From Six Mediabased Ministries,' Nov. 6, 2011, http://www.grassley.senate.gov/news/news-releases/grassleyseeks-information-six-media-based-ministries; John Montague, 'The Law and Financial Transparency in Churches: Reconsidering the Form 990 Exemption', Cardozo Law Review 35 (2013), p. 203.
} 
leaders against wives, children, parishioners, clients, and students. ${ }^{31}$ This two-decades long media and academic narrative of the underside of religion has eroded popular and political support for religious freedom.

Even bigger challenges of late have come with the culture wars between religious freedom and sexual freedom. The legal questions for religious freedom are mounting. Must a religious official with conscientious scruples marry a same-sex or interreligious couple? How about a justice of the peace or a military chaplain asked to solemnise their wedding? Or a county clerk asked to give them a marriage license? Must a devout medical doctor or a religiously chartered hospital perform an elective abortion or assisted-reproduction procedure to a single mother directly contrary to their religious beliefs about marriage and family life? How about if they are receiving government funding? Or if they are the only medical service available to the patient for miles around? Must a conscientiously opposed pharmacist fill a prescription for a contraceptive, abortifacient, or morning-after pill? Or a private employer carry medical insurance for the same prescriptions? What if these are franchises of bigger pharmacies or employers that insist on these services? May a religious organization dismiss or discipline its officials or members because of their sexual orientation or sexual practices, or because they had a divorce, abortion, or IVF treatment? May private religious citizens refuse to photograph or cater a wedding, to rent an apartment, or offer a general service to a same-sex couple whose lifestyle they find religiously or morally wanting - especially when the state's new laws of civil rights and non-discrimination command otherwise?

These are only a few of the headline issues today, which officials and citizens are now struggling to address under heavy pressure from litigation, lobbying, and social media campaigns on all sides. Recent sharply-divided Supreme Court cases on point have only exacerbated these tensions. In Christian Legal Society v. Martinez (2010) and Obergefell v. Hodges (2015), same-sex rights trumped religious freedom concerns. ${ }^{32}$ In Burwell v. Hobby Lobby (2014) and Masterpiece Cakeshop v. Colorado Civil Rights Commission (2018), religious freedom concerns trumped reproductive and sexual freedom claims. The culture wars have only escalated as a consequence. ${ }^{33}$ 'Each side is intolerant of the other; each side wants a total win,' Douglas Laycock write after a thorough study of these new culture wars. 'This mutual insistence on total wins is very bad for religious liberty. ${ }^{34}$ For the first time in American history, the

\footnotetext{
${ }^{31}$ See John Witte, Jr., 'Church, State, and Sex Crimes: What Place for Traditional Sexual Morality in Modern Liberal Societies,' Emory Law Journal 68 (2019), pp. .

${ }^{32} 561$ U.S. 661 (2010) and 135 S.Ct. 2584 (2015).

${ }^{33} 134$ S.Ct. 2751 (2014) and 138 S.Ct. 1719 (2018).

${ }^{34}$ Douglas Laycock, 'Religious Liberty and the Culture Wars,' University of Illinois Law Review (2014), pp. 839, 879.
} 
nation's commitment to religious liberty has moved from the status of 'being taken for granted' to 'being up for grabs. ${ }^{35}$ And with easy political talk afoot about repealing unpopular statutes-not just the Affordable Care Act--legislative protections for religious freedom appear vulnerable, particularly at the state level. Add the fact that both the free exercise and establishment clauses are now much weaker protections than they were a generation ago, and it is hard to resist the judgment of Mary Ann Glendon that American religious freedom is at least in danger of becoming 'a second-class right. ${ }^{36}$ if not expunged altogether in our late modern liberal society.

\section{Returning to First Principles of Religious Freedom}

Constitutions work like 'clock[s],' John Adams reminds us. Certain parts of them are 'essentials and fundamentals,' and, to operate properly, 'their pendulums must swing back and forth' and their operators must get 'wound up' from time to time. ${ }^{37}$ We have certainly seen plenty of constitutional operators get wound up of late about religious freedom, and seen wide pendular swings in First Amendment jurisprudence. But despite the loud criticisms from the academy and media, we may well have come to the end of a long constitutional swing of cases away from religious freedom protection from 1985 to 2010 , and are now witnessing the start of a pendular swing back in favor of stronger religious freedom protection. Since 2011, the last eight Supreme Court cases on religious freedom have all been wins for religion: Arizona Christian School Tuition Organization v. Winn, ${ }^{38}$ Hosanna-Tabor Evangelical Lutheran Church and School v. EEOC, ${ }^{39}$ Town of Greece v. Galloway, ${ }^{40}$ Burwell v. Hobby Lobby Stores, Inc., ${ }^{41}$ Holt v. Hobbs, ${ }^{42}$ Reed v. Town of Gilbert, ${ }^{43}$ Zubik v. Burwell, ${ }^{44}$ and Masterpiece Cakeshop v. Colorado Civil Rights Commission. While Hobby Lobby and Masterpiece Cakeshop have attracted massive popular attention and criticism, these other recent cases

\footnotetext{
${ }^{35}$ Paul Horwitz, 'The Hobby Lobby Moment,' Harvard Law Review 128 (2014), pp. 154, 156.

${ }^{36}$ Mary Ann Glendon, 'Religious Freedom - A Second-Class Right?' Emory Law Journal 61 (2012), pp. 971-990.

${ }^{37}$ John Adams, 'Letter from the Earl of Clarendon to William Pym (Jan. 27, 1766), in George W. Carey (ed.), The Political Writings of John Adams (Washington, DC: Regnery Publishers, 2000), pp. 644, 647 (originally printed in the Boston Gazette, with John Adams using the pseudonym of the Earl of Clarendon).

38563 U.S. 125 (2011).

39132 S. Ct. 694 (2012).

${ }^{40} 134$ S. Ct. 1811 (2014).

41134 S. Ct. 2751 (2014).

42135 S. Ct. 853 (2015).

43135 S. Ct. 2218 (2015)

44 136 S. Ct. 1557 (2016).
} 
have been quietly but steadily shifting First Amendment jurisprudence back in favor of stronger religious freedom.

Moreover, and more gravely, the blood of the many thousands of religious martyrs, especially in the genocidal attacks on communities of faith in the Middle East, Central Africa, and Central Eurasia, is now crying out so loudly that the world community will have to move toward concerted action in protection of religious freedom..$^{45}$ As in Adams's day, so in our own, the United States remains well positioned to provide global leadership in this effort. Most of the core principles of American religious freedom-liberty of conscience, freedom of exercise, and religious equality and pluralism - forged in the crucible of the revolution against religious establishments and oppression are now at the heart of the international human rights protections. And the work of our constitutional courts remains the envy of the world, even if individual cases are denounced.

It is essential, in my view, that these core principles of religious freedom remain vital parts of our American constitutional life and are not diluted into neutrality or equality norms alone, and not weakened by too low a standard of review or too high a law of standing. It is essential that we address the glaring blind spots in our religious freedom jurisprudence-particularly the long and shameful treatment of Native American Indian claims ${ }^{46}$ and the growing repression of Muslims and other minorities at the local level, which are not being addressed very well. ${ }^{47}$ It is essential that we show our traditional hospitality and charity to the 'sojourners within our gates'48 - migrants, refugees, asylum seekers, and others-and desist from some of the outrageous nativism and xenophobia

\footnotetext{
${ }^{45}$ See Daniel Philpott and Timothy Shaw, Under Caesar's Sword: How Christians Respond to Persecution (Cambridge: Cambridge University Press, 2018); Brian J. Grim and Roger Finke, The Price of Religious Freedom Denied: Religious Freedom and Conflict in the Twenty-First Century (Cambridge: Cambridge University Press, 2011).

${ }^{46}$ See, e.g., Lyng v. Northwest Indian Cemetery Protective Association, 485 U.S. 439, 451 (1988) (rejecting a challenge to the federal government's logging and road construction activities on lands sacred to several Native American tribes, even though it was undisputed that these activities 'could have devastating effects on traditional Indian religious practices'); Employment Division $v$. Smith, 494 U.S. 872 (1990) (holding that the state may prohibit the sacramental use of peyote in Native American Church); Bowen v. Roy, 476 U.S. 693 (1986) (holding that an agency's use of a social security number does not violate the free exercise rights of a Native American, who believed such use would impair his child's spirit). See also Kathleen Sands, 'Territory, Wilderness, Property, and Reservation: Land and Religion in Native American Supreme Court Cases,' American Indian Law Review 36 (2012), p. 253.

${ }^{47}$ But see the recent case of Herrara v. Wyoming (slip op. May 20, 2019) (upholding Crow Indian treaty claims to hunting rights). On the harsh treatment of Muslims in lower federal courts, see, e.g., Gregory C. Sisk and Michael Heise, 'Muslims and Religious Liberty in the Era of Post 9/11: Empirical Evidence from the Federal Courts,' Iowa Law Review 98 (2012), p. 291. But see Holt v. Hobbs, 135 S. Ct. 853 (2015) (upholding a Muslim prisoner's statutory religious freedom to sport a longer beard than local prison regulations permitted).

${ }^{48}$ Exodus 20:10.
} 
that have marked too much of our popular and political speech of late. ${ }^{49}$ It is essential that we balance religious freedom with other fundamental freedoms, including sexual and same-sex freedoms, and find responsible ways of living together with all our neighbors, and desisting from mutually destructive strategies of defaming, demonizing, and destroying those who hold other viewpoints. ${ }^{50}$ And it is essential that we make our landmark International Religious Freedom Act ${ }^{51}$ a strong focus of our international diplomacy and policy again, not something to be ignored when economic, military, or geo-political interests get in the way, or deprecated and underfunded when other special administration interests gain political favor. $^{52}$ Now is the time for American governments, academics, NGOs, religious and political groups, and citizens alike to stand for strong religious freedom at home and abroad, for all peaceable people of faith.

Religion is too vital a root and resource for democratic order and rule of law to be passed over or pushed out. Religious freedom is too central a pillar of liberty and human rights to be chiseled away or pulled down. In centuries past-and in many regions of the world still todaydisputes over religion and religious freedom have often led to violence, sometimes to all-out warfare. We have the extraordinary luxury in America of settling our religious disputes and vindicating our religious rights and liberties with patience, deliberation, due process, and full ventilation of the issues on all sides. We would do well to continue to embrace this precious constitutional heritage and process, and help others to achieve the same. As John Adams reminds us: ' $[T]$ he eyes of the world are upon [us]. ${ }^{53}$

\footnotetext{
${ }^{49}$ See, e.g., Robert Heimburger, God and the Illegal Alien: Federal United States Immigration Law and a Theology of Politics (Cambridge: Cambridge University Press, 2018).

${ }^{50}$ See overview in John Witte, Jr., Church, State and Family: Reconciling Traditional Teachings and Modern Liberties (Cambridge: Cambridge University Press, 2019).

5122 U.S.C. $\S 6401$ (2012).

${ }^{52}$ See, e.g., Thomas F. Farr et al., 'Religious Liberties: The International Religious Freedom Act,' Houston Journal of International Law 31 (2009): 469, 478-79 ('The International Religious Freedom Act [IRFA] . . w was passed ten years ago. That law aimed to put religious freedom advocacy at the heart of U.S. foreign policy. . . . For the past ten years, the international religious freedom office [and IRFA] and U.S. democracy promotion efforts have been like two ships passing in the night — nothing to do with each other whatsoever. This needs to change.').

53 Adams, Works, vol. 8, p. 487.
} 